BITÓ János - CZERNY József

\title{
A BALANCED SCORECARD ALKALMAZÁSA EGY TERMELŐ VÁLLALAT LÉTESÍTMÉNY- GAZDÁLKODÁSI FUNKCIÓJÁRA
}

A cikk egy termelő vállalat létesítménygazdálkodási területén bevezetett Balanced Scorecard kialakítását írja le. Bemutatja a létesítménygazdálkodás - érvényes európai és magyar szabványok szerinti - értelmezését, illetve a kiegyensúlyozott mutatószámrendszer fóbb jellemzőit, a kialakításához kapcsolódó általános feladatokat. Részletesen ismerteti, hogy a termelô vállalat e funkciójához kapcsolódóan milyen kihívásokkal kellett szembenézni a vizsgált vállalatnál és miért esett a választás az alkalmazott stratégiaimenedzsment-eszközre. Áttekinti, hogy a vizsgált vállalat létesítménygazdálkodási területének kialakított Balanced Scorecardjában milyen nézốpontok, célok és kiemelt mutatók szerepelnek, és hogyan lehet azokat kialakítani olyan módon, amely a késóbbi benchmarkingra is lehetôséget ad.

\section{Kulcsszavak: Balanced Scorecard, kiegyensúlyozott mutatószámrendszer, létesítménygazdálkodás}

Jelen tanulmányban egy nyugat-magyarországi termelő vállalat létesítménygazdálkodási területére bevezetett Balanced Scorecard történetét mutatjuk be. A vállalat létesítménygazdálkodási területén jelentôs problémát okozott, hogy a funkció vállalati sikerességhez való hozzájárulását nem lehetett bemutatni. A vállalat vezetése a létesítménygazdálkodásról nem rendelkezett pontos képpel: nem tudták, pontosan milyen szolgáltatásokat nyújtanak. Számukra csak az volt ismert, hogy a területnek mekkora büdzséje van, s hányszor volt olyan üzemzavar, amely e terület felelósségébe tartozott. Ennél kifinomultabb megoldást kerestek.

A létesítménygazdálkodás elmélete ma Magyarországon gyerekcipőben jár: nincs kifejlett módszertana, de még a létesítménygazdálkodás területén dolgozók körében sem egységes az értelmezése, sôt, talán különösen ott nem. A Balanced Scorecard (BSC) lényegesen ismertebb módszer, jelentős magyar nyelvú szakirodalom, vállalati esettanulmány létezik ebben a témában (IFUA Horváth \& Partners, 2008). Ugyanakkor a BSC-t elsôsorban vállalati stratégia lebontására, célok kommunikálására használják, s csak nagyon ritkán egy funkció értékelésére.

$\mathrm{Az}$ általunk ismert hazai példák egyikében sem alkalmazták a BSC-t a létesítménygazdálkodás területére, illetve nem ismert olyan alkalmazása ennek a menedzs- menteszköznek, mint amire a jelen írásban részletezett esettanulmányban sor került.

Két irányból közelítettünk a megoldás felé:

A vállalat stratégiai céljainak feltárásával a projekt meghatározta a létesítménygazdálkodási funkció stratégiai térképét (Kaplan - Norton, 2004). Ez tartalmazta azokat a célokat, amelyeket ennek a funkcionális területnek követnie kell, így elérésükkel, teljesítésükkel lehet mérni a létesítménygazdálkodás eredményességét.

A másik irány a kutatócsapat által korábban kidolgozott szolgáltatási szint megállapodások részletesebb kidolgozásából adódott. A létesítménygazdálkodási területhez nagyszámú szolgáltatás kapcsolódik, amelyeknek a mérhetôségét már korábban is igyekezett a vállalat megteremteni. A méréshez használt mutatókat kellett részben újradefiniálni, majd a kialakított mutatószámokat a stratégiai térképhez kapcsolni.

\section{Az alkalmazott módszertan}

A projektmunka, a kutatási munka során a jól bevált BSCmódszertant követte a feladatra összeállított csapat ${ }^{1}$ :

- a kutatási irányok megfogalmazása, szakirodalmak, vállalati példák gyújtése, elemzése, 


\section{Egy általános Balanced Scorecard felépítése}

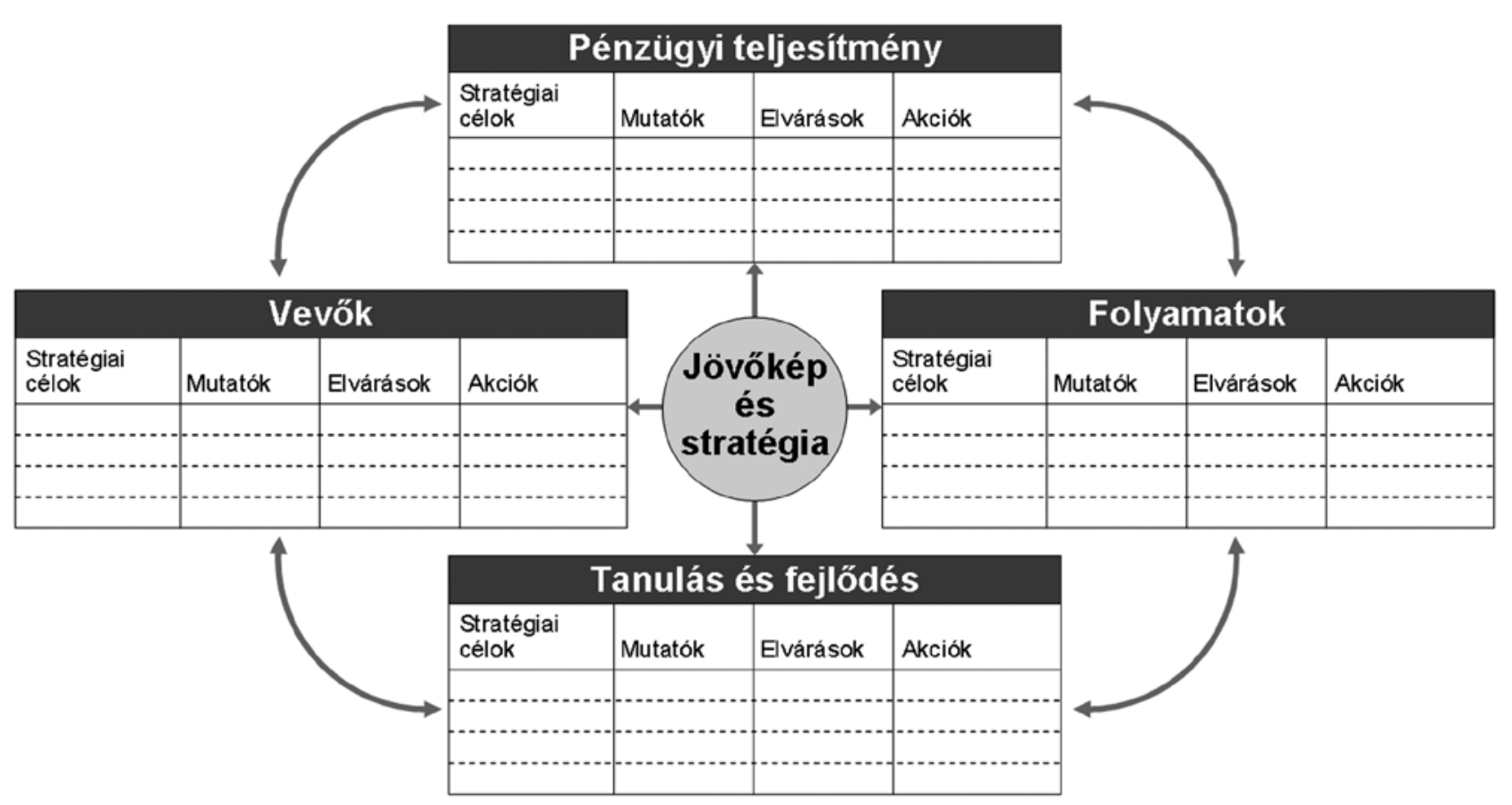

- a vállalat meglevő gyakorlatának értékelése kiscsoportos megbeszélések segítségével,

a nemzetközi szakirodalom feldolgozása, az iparági legjobb gyakorlatok vizsgálata,

a kutatás eredményeinek megvitatása munkaértekezletek keretében,

az elfogadott megállapodásoknak egy átfogó dokumentumba való rögzítése, amely egyben fó forrása is a jelen tanulmánynak.

A munka során összesen tíz alkalommal tartott csoport munkamegbeszéléseket, amelyek során me vitatták a fellelt szakirodalmat, a vállalati esettanulmányokat. Mindemellett a bevont szakemberek önálló kutatómunka során gyújtötték és rendszerezték a fellelhetô információkat, keresték meg az analog lönböző más területekkel.

\section{A Balanced Scorecardról általában}

A Balanced Scorecard alapvetôen a stratégia konkretizálásának, ábrázolásának és nyomon követésének sajáto módját jelenti. Segítségével nagyobb valószínúséggel valósítható meg a bevezetendó stratégia, és helyesen értékelhetố a vállalat értékteremtố képessége. Magát koncepciót a kilencvenes évek elején fejlesztette ki Robert S. Kaplan professzor vezette amerikai kutatócsoport a Harvard Egyetemen. Kaplan és csapata a Balanced Scorecard nevet adta a koncepciónak, ezzel fejezve azt, hogy olyan kiegyensúlyozott (balanced) rendszerról van szó, amely egyértelmúen az eredmény mérésére (scorecard) vállalkozik (Kaplan - Norton, 2000).

Azonban hamarosan kiderült, hogy a Balanced Scorecard ennél többre képes: a célok és mutatószámok megfeleló kiválasztása esetén világossá és egyidejúleg mérhetővé is teszi a szervezet stratégiai csapásirányait (l.ábra).

A Balanced Scorecard ennek során hasznosítja azt a motivációs elméletek által alátámasztott összefüggést, hogy a célok befolyásolják a viselkedést. A cúlok he-

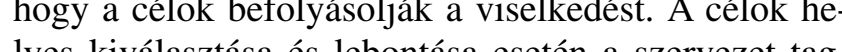
join kivalasztása és lebontása esetén a szervezet tagjainak beáliltottsága összhangba hozható a stratégia núbbé válik (Bakacsi, 1996).

A Balanced Scorecard megközelítésmódjának alapja, hogy a célokat, mutatószámokat és stratégiai akciókat mindig egy-egy konkrét nézóponthoz (perspektívához) rendeli hozzá. A nézópontokhoz való hozzárendelés célja, hogy megakadályozza az egyoldalú gondolkodást a célok levezetése és követése során. A rendszer e helyett a nézőpontokban való gondolkodás és a nézôpontok összekapcsolása révén dokumentálja a stratégia megvalósítás lényeges összefüggéseit.

A Balanced Scorecard megalkotói empirikus tapasztalatok alapján először a következő négy lényeges nézốpontot javasolták:

$$
\text { pénzügyi, }
$$

vevók, követelményekkel, melyek megvalósítása így valószí-

\section{- belsố folyamatok, valamint}

tanulás és fejlődés.

Ezek a nézôpontok könnyúszerrel az üzletág és a vállalat jellemzóihez igazíthatók. A tanulás és fejlódés nézôpontot például szívesen nevezzük „,potenciálok” nézópontnak is, mivel a sikeres jövốt megalapozó képességeket, potenciálokat írja le.

A kiegyensúlyozott stratégiai mutatószámrendszerhez - azaz a „Balanced Scorecard”-hoz - az vezet, hogy a nézópontokat egyenrangúan (kiegyensúlyozottan) vesszük figyelembe a stratégiai célok levezetése során.

A Balanced Scorecard egyik nagy elónye tehát, hogy a szervezetek az elfogadott, kommunikált stratégia irányába tudtak elmozdulni (Kaplan - Norton, 1996). Ehhez biztosít a BSC egy olyan rugalmas keretet, amelyet a vállalat vezetése mindig a megfeleló módon tud átalakítani, testre szabni, és így a vállalo vezetése és a végrehajtási szinteken dolgozók vözö

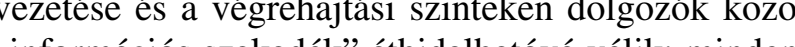
számára ismertek lesznek a követendó irányok, elérendô célok.

Különösen fontos ez egy olyan stratégiai jelentóségú, de egyelôre igen kis presztízsú terület esetén, mi a létesítménygazdálkodás.

\section{A létesítménygazdálkodásról általában}

Mivel azzal a kérdéssel, hogy mi is a létesítménygazdálkodás, neves közgazdászprofesszorokat is zavarba lehet hozni, célszerúnek látszik röviden összefoglalni miról is van szó (Keit, 1996).

Talán meglepő, de 2006 óta érvényes magyar szabvány van rá, az MSZ EN 15221-1.

Ha kellóen átgondoljuk, világos lehet, hogy kivétel nélkül minden szervezet felhasznál fơ tevékenysége támogatására bizonyos eszközöket és szolgáltatásokat, amelyek nélkül a fố tevékenységnek, és így magának a szervezetnek a múködése, és sok esetben a puszta léte is elképzelhetetlen. Ezeknek az eszközöknek és szolgáltáśn menedzselésével foglalkozik a létesítménygazdálkodás (angol kifejezéssel facilities management) ${ }^{2}$.

A létesítménygazdálkodási szolgáltatások a támogató üzleti szolgáltatások körébe tartoznak. A szervezete igen nagyszámú létesítménygazdálkodási szolgáltatás használnak fel múködésük során, a szolgáltatások ált előállított értéktöbblet beépül a szervezet által előálltott végtermékekbe.

A szervezetek által igénybe vett létesítménygazdálkodási szolgáltatások száma száz és kétszáz között vâltozik. A szolgáltatási kör magában foglalja például: az épületekhez kapcsolódó szolgáltatásokat - az épület maga, épületüzemeltetés, épület-karbantartási és egyéb múszaki szolgáltatások, takarítás, az energiamenedzsment, ôrzés-védelem, ezek kerültek esetünkben elötérbe,

a munkavégzéshez kapcsolódó szolgáltatásokat étkezési szolgáltatások, munkahelyi egészségügyi szolgáltatások, információs és kommunikációs szolgáltatások, helyi katasztrófamegelózés és -elhárítás, létesítmények túzbiztonsági szolgáltatásai, bútorozás, költözések, vagyonvédelem, munkavédelem, területmenedzsment stb.

Csak néhányat találomra kiemelve ${ }^{3}$ :

A létesítménygazdálkodás mint szervezeti funkció feladata, hogy üzletileg optimális szinten biztosítsa az egész szervezet létesitménygazdálkodási szolgáltatások iránti szükségletének kielégitését. Tevékenysége során a változások kezelésével alapvetôen befolyásolja a szervezet múködését, a dolgozók közérzetét, a szervezet múködésének hatékonyságát (Keit, 1996).

A létesítménygazdálkodási szolgáltatások fó jellegzetessége, mint az üzleti szolgáltatásoké általában, hogy azokat helyben állítják eló és a szervezetek azokat a múködésük helyén veszik igénybe.

A Magyarországon felhasznált létesítménygazdálkodási szolgáltatásokat szinte kizárólag a kis- és közepes vállalatok (KKV-k) nyújtják, más kérdés, hogy zokat milyen szervezet értékesíti

A létesítménygazdálkodás mint modern menedzsmentdiszciplína az utóbbi 15 évben alakult ki. Hajtóereje a szervezetek belsố szolgáltatásainak optimalizálása iránti igény volt.

Tanulmányunkkal kapcsolatban fel kell hívnunk egy fontos korulményre a figyelmet. Az altalunk itt leírt módszer alkalmazása úttörő jellegúnek számít Magyarországon, és ez sokakat a módszer mechanikus másolására indíthat. De ez komoly tévedés.

Másrész az ilyen jellegú piac, azaz a létesítménygazdálkodási vezetési tanácsadási piac olyan mértékben éretlen, a létesítménygazdálkodási szervezetek vezetối igen sokszor olyan mértékben felkészületlenek, hogy a szolgai másolás hátrányai esetleg ritkán vagy soha sem derülnek ki.

A létesítménygazdálkodás, mint üzleti diszciplína nálunk még hiányzó szakmai szabályai miatt, még a látszólag hasonló szervezetek is alapvetóen eltéróen múködhetnek, így a mellékletben felsorolt teljesítménymutatók szolgai másolása biztos jele lehet az azokat alkalmazni kívánók hiányos felkészültségének.

Persze az ilyen figyelmeztetések pontosan az abban leginkább érintettekhez nem jutnak általában el. 


\section{A Balanced Scorecard kialakításakor} végrehajtandó általános feladatok

\section{Stratégiai célok kijelölése}

Elsố lépésként célokat kell meghatározni. Célok alatt azokat a lényeges irányvonalakat értjük, amelyek befolyásolják mind a vezetố, mind a végrehajtó munkatársak cselekedeteit. Az ilyen célok meghatározás és elóírása a vezetés legfóbb feladata.

Érdemes kisszámú célt meghatározni. A szakirodalomban (IFUA Horváth \& Partners, 2008) a twenty is plenty" mondés tartja maǵt, amely kifejezi, hogy maximum a 4 nézóponto összesen 20 cét érdeges felállítani. Ennél több már zavart okozhat: nehéz megjegyezni, még inkább követni azokat.

A szakirodalom általános célokat fogalmaz meg, de a legtöbb helyen kiemelik, hogy a ,általános célok" vagy ,iparági standard célok” nem léteznek. Ahogy nem létezik ugyanis két teljesen azonos vállalat, ugyanúgy nem létezik két teljesen azonos stratégia, de felsô vezetés sem.

\section{Stratégiai térkép elkészítése}

Az előző lépésként meghatározott stratégiai célokat egy írott oldalon javasolják (Kaplan, Robert S.

Norton, David P., 2000) ábrázolni, így ugyanis a célok közötti összefüggések, esetleges ellentmondások könynyen egyértelmúvé tehetók

A stratégiai térkép elfogadása után jól használható a belsố kommunikációra is: könnyen áttekinthetố, mive csak egy oldal, és egyszerúsége miatt pozitív érzelm hatást válthat ki az érintettekbő́l.

\section{Mutatószámok meghatározása}

A mutatószámok segítségével válnak mérhetôvé, ellenôrizhetôvé az elfogadott stratégiai célok. A mutatók kulcsszerepet töltenek be a BSC-megközelítésben.

Ugyanakkor a szokásos, kifejezetten pénzügyi mutatókhoz képest itt több más nézôpont mutatója is szerepel: így válik kiegyensúlyozottá a mutatószámrendszer (ami a Balanced Scorecard leggyakoribb magyar fordítása is).

\section{Célértékek meghatározása}

Amennyiben a mutatószámokat, azaz azokat a dimenziókat, amelyek mentén a vezetés az egyes nézópontokat értékelni fogja, a vállalat meghatározta, egyes mutatókhoz célértékeket kell meghatározni.

A célok meghatározása, kijelölése általános menedzsmentfeladat: mennyire legyenek kihívóak, mennyire térjenek el a jelenlegi állapottól - ezek mind olyan kérdések, amelyekkel az általános me- nedzsment-szakirodalom vagy a motivációelméletek foglalkoznak. Ennek meg-felelően jelen dokumentumunkban ezzel a körrel nem foglalkozunk részletesebben

\section{Stratégiai akciók kijelölése}

Ha a célok kidolgozásával elkészültünk, meg kell határoznunk, miként fogjuk azokat mérni, milyen célértékeket kívánunk elérni. Ehhez ki kell jelölni azokat az akciókat, amelyek a megvalósítást szolgálják. Hasonlóan a célértékek kijelöléséhez, ez olyan áltaĺnnos menedzentfelada tomek igen részletes a szak, jum irodalma, így jelen tanulmányban e témával nem fogteszletesebben.

Ha mindezeken a lépéseken a vállalat végigmegy, a szakirodalmi ajánlások és a különböző vállalati esettanulmányok alapján jól múködő Balanced Scorecardot ud kialakítani.

A szakirodalomban több hivatkozás található (IFUA Horváth \& Partners,2008), hogy Balanced Scorecard nem csak egy egész vállalatra vonatkozhat: több szintje létezik.

Egy nagy autóalkatrész-beszállító vállalat esetében, amely 3 kontinens 40 országában van jelen, például a cégcsoportnak van konszernszintú BSC-je, és az egyes gavállalatok ebból vezetik le saját BSC-rendszeriket, es emellett a vállo

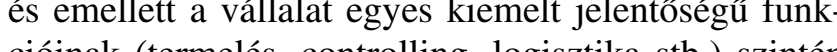
ciónak (termeles, controlling, logisztika stb.) szintén van saját, az egész konszernt áfogó BSC-rendszere. Ezek a BSC-rendszerek logikai hálót alkotnak: a magasabb szint BSC-je meghatározza az alacsonyabb szintek BSC-jeit, kijelöli a kereteket. A vállalatcsoport így tudja biztosítani a stratégiai összhangot a földrajzilag és gyártmány szempontjából is igen szerteágazó múködés mellett.

A jelen tanulmány forrását képezô projekt során éppen az ellenkező módon jártunk el.

Nem lévén konszern és vállalati szintú kiegyensúlyozott mutatószámrendszer, egy üzleti terület, belsô funkció BSC-rendszerét kellett úgy felépíteni, hogy az késóbb hozź́idónthó ́ó legyen az esetlegesen kiagy az

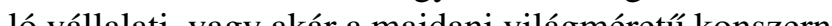
ló válla szintú BSC-rendszerhez.

\section{Á́tesítménygazdálkodási funkció esetében}

A Balanced Scorecard jól alkalmazható egy vállalatcsoport vagy egy vállalat stratégiájának lebontásakor, annak kommunikálásánál, illetve az elért eredmények mérésére. Ezeket összefoglalóan a szakirodalomban stratégiai controlling feladatnak hívják.
A konkrét esetben nem arra volt szükség, hogy a vállalat általános stratégiáját fordítsa le a vezetés célokra, mutatókra, s azt kommunikálja a tagok felé. Az volt a feladat, hogy olyan módszert dolgozzunk k amely segít a vállalat vezetése, a többi terület számára, hogy megértse és átlássa a létesítménygazdálkodás tevékenységét, így a vállalati eredményességhez történ hozzájárulása is világos legyen az érintettek számára.

Egy olyan gyártó vállalat esetében, mint amilyen feldolgozott példa is, a létesítménygazdálkodási funkciónak stratégiai szerepe van: a termeléshez szïkséges

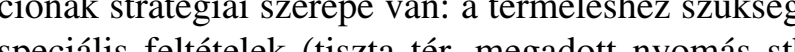
biztosítása kritikus jelentőségú (Dilanthi AmaratungaDavidtosíása kritikus jeldry, 2002).

Ebbő́l ugyanakkor a többi terület igen keveset ész lel, csak az egyes vezetói értekezleteken találkoznak területtel, és akkor is csak két összefüggésben:

hogyan állnak a költségkeretükhöz képest,

és milyen rendkívüli esemény volt az utóbbi idó-

ben, amely a termelés, az üzletmenet folytonosságát veszélyeztette.

Éppen ezért, illetve a projekt során elvégzett, a létesítménygazdálkodási funkció érettségére vonatkozó vizsgálatok alapjén, amelyeket itt nem részlezezink, szïksé́gesnek látszott, hogy olyan kommuniḱciós közt kezden el haszíni ez a ter amely a többi érintett számára egyértelmúvé teszi, hogy

- mivel foglalkoznak,

ezek a feladatok hogyan kapcsolódnak a vállalat eredményességéhez,

a feladatokat milyen színvonalon látják el.

A szakirodalom feldolgozása után egyértelmúvé vált, hogy létesítménygazdálkodási területen nagyon ritka ezen eszköz használata: egyáltalán nem leltünk fel olyan magyar nyelvú publikációkat, amelyek foglalkoznának e területtel, ezért más vállalati területeken használt funkcionális BSC-ket vizsgáltak meg a munkacsoport tagjai.

A legtöbb hasonlóságot, analógiát az informatikai szervezetekre kialakított mutatószámrendszerek logikájával lehetett találni. Az informatika ugyanis szintén olyan szolgáltatás, amely esetében a hordozó közegnek nagy a szerepe (hálózat, számítógépek), de nem maga a hordozó közeg a szolgáltatás, hasontón a lótesít-

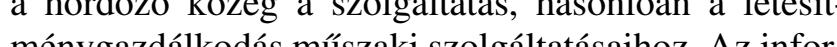
mén matikai szolgálatások eseten hazánkban is tobbnyire magat erelorik, hogy a szolgallatasokrol SLA-kat, szolgaltatásiszint-megallapodásokat kötnek. Az SLA-k tartalmazzák az informatikai szolgáltatások elvárt minőségét, mutatóit (KPI-ket, azaz kulcs teljesítménymutatókat, key performance indicators).

Az informatikai szolgáltatások analógiájára építve a munkacsoport egyetértett abban, hogy ez a menedzsmenteszköz (BSC) a létesítménygazdálkodás területén is alkalmazható lesz.

A létesítménygazdálkodási Balanced Scorecard kialakításának lépései

Az angol nyelvú szakirodalmat (Paul Coronel - Anne Evans, 1999, Rick Best - Craig Langston - Gerard de Valence) tanulmányozva a munkacsoport tagjai az alábbi folyamatot követve dolgozták ki a létesítménygazdálkodási funkció BSC-jét:

A vállalat esetében a létesítménygazdálkodáshoz kapcsolódó operatív feladatok jelentốs részét külső szolgáltatók látják el. A szolgáltatóval folyamatban volt tóval fúj típán volt dés megkôté szerzolyek szolgáltatásiszintmek szolgálatasiszintmegáll a podás sokra épülnek. A terv az volt, és ez összevágott a BSC felállitásának tervével, hogy a szolgáltatási szinteket a létesítménygazdálkodási terület a későbbiekben folyamatosan fogja vizsgálni, kiértékelni.

A Balanced Scorecard kialakításának menete

\section{VEZETÉSTUDOMÁNY}

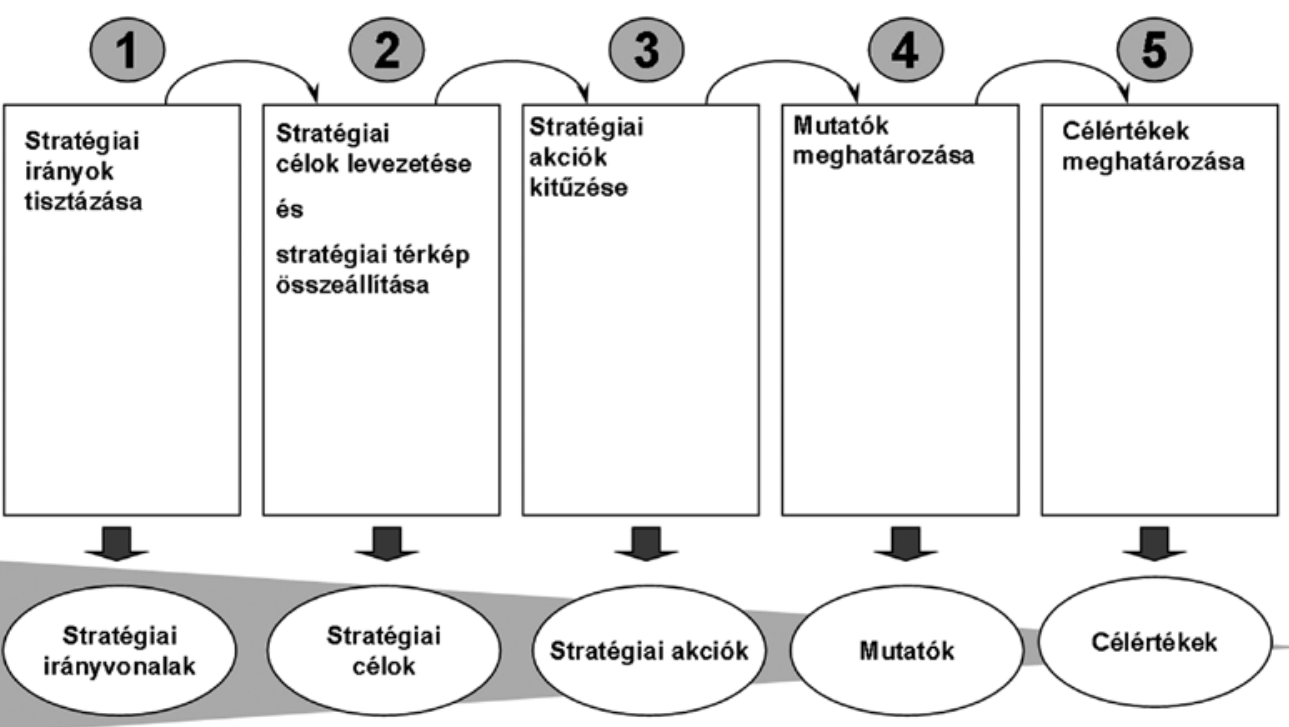


1. Stratégiai irányok tisztázása Ezekben többek között az is, szerepel, hogy a következő idôszakban a vállalat vezetése milyen dimenzióa stratégiai célokat. A munka terjedelmébe nem tartozott bele természetesen a vállalat vagy a vállalatcsopo stratégiájának felülvizsgálata, módosítása.

\section{Stratégiai célok levezetése, stratégiai térkép} összeállitás

Az előző pontnak megfelelóen áttekintett személye célok vizsgálata, illetve a vállalat további szakterületeménygazdálkodási terület stratégiai céljai.

Ebben tehát szerepeltek a vállalatvezetés elvárása (a személyes célokból kiindulva), illetve szerepeltek a társosztályok elvárásai is (a múhelymunka eredményét becsatornázva). E módszer helyett a szakirodalmakban kifejezetten a többkörös workshopok megtartását javavolt lehetôség, így ezt a munkamódszert fogadták el közremúködók. A munka eredményeként a vállalat létesítménygazdálkodási területének stratégiai térképe 3. ábrán látható módon alakult ki.
A vállalat vezetése az egyes területek számára sokszor, mint esetünkben is személyes célokat határoz meg. kat követve kíván fejlesztéseket végrehajtani.

Ezekre alapozva határozta meg a szakértói csapa inek bevonásával múhelyvitában alakultak ki a létesítsolják. Ugyanakkor erre a munka ezen fázisában nem

üzembiztonság nézőpont

fejlódés-innováció nézőpont.

A Pénzügyi nézópont gyakorlatilag minden ismert vállalat BSC-jében, stratégiai térképén szerepel. A tulajdonosok számára általában az a legfontosabb: befektetett tókéjük megtérülését ez mutatja meg. A létesítménygazdálkodási terület esetében árbevételi célokat nyilvánvalóan nem lehet meghatározni: ez a terület ugyanis nincsen olyan kapcsolatban az üzleti környezetével, ahonnan árbevétele származna. Ennek megfelelôen itt profitcélok megtérïlés és jövedelmezőség lelốn ík $\mathrm{p}$ mután mutatók se nos kölsécsuk A Veor Ezeket fejezik ki az elfogadott célok.

A Vevók-szallitók nézópont a szakirodalom ,standard" Balanced Scorecardjában nem eb-ben a formában szerepel. Általában, amikor egy vállalat egészére vonatkoztatjuk a BSC-t, akkor többnyire a vevókre koncentrálunk: a vevốk és a vevôi kapcsolatok határozzák meg a társaság sikerét, innen származik az árbevétel, így az ide való koncentrálás teljesen termé-szetes. A vizsgált vállalat esetében a vállalati szintú $\mathrm{BSC}$-ben természetesen lenne értelme külön vevói nézópontot szerepeltetni. Ugyanakkor a létesítménygazdálkodási területen -a pénzügyinézópontnál leírt okok miatt-nincsértelmekifejezetten erre a csoportra a vállatat vevóire fókuszálni. A lététín 3. ábra vannak vevói, de azok vállalaton belül található további területek (azaz az ún. belsố vevốk, pl. a termelés). A belsố vevói igényeknek természetesen meg kell felelni. A vevôi oldalról származó feladatok ellátása mellett a szállítói kapcsolatoknak van kiemelt jelentôsége. A terïlet operatív múködésének nagy tív múkódésének nagy

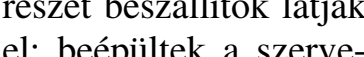
el: beépültek a szervezet munkafolyamataiba, igy megfelelő színvonalú múködésük kritikus \begin{tabular}{r|r} 
Mint az a 3. ábrán is látható a munkacsoport - a & a vállalat sikeressége szempontjából. E szállítókkal a \\
szakirodalomból (Kaplan - Norton, 2000) kiindulva, a & létesítménygazdálkodási szervezet tartja a kapcsolatot,
\end{tabular} szokásos gyakorlatot végiggondolva - az alábbi dimen- így e szervezet BSC-jében - a szállítók kritikus jelentốziókat alakította ki:

pénzügyi nézópont,

vevők-szállitók nézőpont, nyok áttanulmányozásakor nem találtunk meg másutt. A nézôpont alkalmazásának fố oka, hogy a vállalat termelő rendszereinek igen magas rendelkezésre állást kell teljesíteniük, így az azokat kiszolgáló rendszereknek is. Az üzembiztonságba mind a rendszerek rendelkezésre állását, mind pedig a baleseteket beleértettük, és ennek megfelelóen alakultak ki a vonatkozó stratégiai célok is. A magasan biztosított kockázati szin egy olyan speciális, csak a létesítménygazdálkodási területen (esetleg biztosítási területeken) értelmezhetó jellemzốt takar, amely azt írja le, hogy egy adott t́r ság milyen lépéseket tesz a balesetek és egyéb, hasonló kockázatok elkerülése érdekében.

A negyedik nézôpont a klasszikusnak mondhat Fejlódés-innováció. Ez foglalja össze mind a munkatársak, mind pedig az egyes rendszerek fejlesztésével, kutatásokkal kapcsolatos célokat. Ez a nézópont gyakorlatilag minden BSC-ben megtalálható, és általába is a vállalat hosszú távú sikeres múködése alapjának szokták tartani.

\section{A Balanced Scorecard és a szolgáltatási-szint} megállapodások összekapcsolása

A munka utolsó fázisában arra kerestïk a választ, hogy a vállalat esetében a definiált létesítménygazdálkodás szolgáltáásokat jellemző teljesítme értékeit hogyan lehet a BSC-ben szereplő stratégiai célokhoz kapcsolni (Dilanthi Amaratunga - David Baldry - Marjan Sarshar, 2000).

Ehhez a következó feladatokat kellett végrehajtani: Ehhez a következó feladatokat kellett végrehajt

- a szolgáltatások egyértelmú meghatározása; amelyekkel a szolgáltatási színvonalat lehet je lemezni;

a mutatószámok és a stratégiai célok közötti kapcsolatok meghatározása.

A szolgáltatások színvonalának megítéléséhez a szakirodalmak és vállalati esettanulmányok (case studies) tanulmányozása alapján az EN $15341^{4}$ szabványban felsorolt mutatók túntek a legalkalmas

Az európi szabvány haszálát indokolta aza teny Az europaíl is, hogy a vallalatcsoport Europa számos országába van jelen, ahol szintên feladat a szolgáltatások megítélése. Az egyes országokban múködő gyárak létesít ménygazdálkodása teljesítményének összehasonlíth tóságát (benchmarkingját) csak úgy lehet biztosítan ha mindenhol ugyanazt az elfogadott mérőrendsze alkalmazzuk. Ennek megfelelóen a munkacsoport számítva az itt leírt módszerek egész vállalatcsoporto belüli kiterjesztésével - az idézett EN szabvány alapján határozták meg a szolgáltatási mutatókat. Az egyes szolgáltatásokhoz rendelt teljesítménymutatókat szinén a melléklet tartalmazza.

A stratégiai célok, mutatók és az SLA-kban szereplố mutatók jelentôsen eltérnek egymástól, hiszen egészen más célokat szolgálnak, mások a jellemzóik.

A Balanced Scorecardban szereplő mutatók jellemzói (IFUA Horváth \& Partners, 2008)

csak a kiemelt stratégiai területekre koncentrálnak; logikai láncra vannak felfúzve;

- a tervértékeik a stratégiából kerülnek levezetésre;

hosszabb idótávra fogalmaznak meg elvárásokat: kommunikálják a stratégiát.

Ezzel szemben az SLA-kban szereplő mutatók: - nem teljes körúek, még a létesítménygazdálkodási funkció teljes körét sem fedik le;

nincsenek, vagy nem okvetlenül vannak ok-okozati kapcsolatok közöttük;

a tervértékeket nem mindig a stratégiából vezetik le;

- rövidebb idôtávra határoznak meg célértékeket;

- nem kommunikálják a stratégiát.

Ennek megfelelóen mindig lesznek olyan stratégiai célok, amelyekhez nem lehet valamely létesítménygazdálkodási szolgáltatás SLA-mutatóját hozzárendelni, hiszen az elóbbiek nem közyetlenül kapcsolódnak vaamely szolgáltatáshoz, vagy azok csoportjához.

Esetünkben a stratégiai célok és a szolgáltatások definiált mutatói közötti kapcsolatot az 1. táblázat tartalmazza.

Az egyes SLA-mutatók definiálásánál az EN 15341 - Maintenance - Maintenance Key Performance Indicators szabványból indultunk ki, az egyes SLAmutatók elnevezése is a szabványt követi.

\section{Összefoglalás}

A projekt egyik fő tanulsága volt, hogy érdemes további mutatókat kijelölni azon stratégiai célokra, amelyeket létesítménygazdálkodási és a vállalat vezetối is fonosnak tartanak, de konkrét SLA-mutatót nem lehetet vagy nem volt érdemes kidolgozni ebben a fázisban.

Minderre a késóbbi munka során, a jelen tanulmányban leírtak alkalmazási tapasztalatait felhasználva kerülhet sor.

Megítélésünk szerint távlatilag így lesz a létesítménygazdálkodási területre kidolgozott Balanced Scorecard teljes értékú.

A Balanced Scorecard alkalmazás egy eddig többnyire elhanyagolt, de stratégiailag fontos területre azért jelentốs, mert apró, de talán nem jelentéktelen hozzájárulás lehet egy fontos, de egyelốre nem kellóen felismert szolgáltatási ipar öntudatra ébredéséhez.

\section{VEZETÉSTUDOMÁNY}


Az egyes célokhoz rendelt mutatók

\begin{tabular}{|c|c|}
\hline Stratégiai cél & SLA-mutató neve \\
\hline Relatív költségek csökkenése & $\begin{array}{l}\text { E1: Teljes karbantartási költség / eszközpótlási költség × } 100 \\
\text { T2: Eszközök múködési ideje (tény) / Eszközök elvárt múködési ideje x } 100 \\
\text { T6C: Üzemzavar miatt kieső idő / (Teljes múködési idő + üzemzavar miatt kiesô } \\
\text { idő) × 100; a rendszerre vonatkozóan } \\
\text { T21: Hiba utáni helyreállításig eltelt idő (ösz-szesítve) / hibák száma }\end{array}$ \\
\hline Költségkeret betartása (fit to plan) & E1: Teljes karbantartási költség / eszközpótlási költség × 100 \\
\hline Büntetések elkerülése & S1: Sikertelen hatósági vizsga / hatósági vizsga × 100 \\
\hline Vevôi elégedettség javítása & $\begin{array}{l}\text { T2: Eszközök múködési ideje (tény) / Eszközök elvárt múködési ideje × } 100 \\
\text { T6C: Üzemzavar miatt kieső idő / (Teljes múködési idó + üzemzavar miatt kieső } \\
\text { idô) × 100; a rendszerre vonatkozóan } \\
\text { T17: Teljes üzemelési idő / hibák száma × } 100 \\
\text { T21: Hiba utáni helyreállításig eltelt idő (összesítve) / hibák száma }\end{array}$ \\
\hline Beszállítói partnerség kialakítása / erôsítése & Nincs megfelelő SLA-mutató \\
\hline $\begin{array}{l}\text { Vevői igények fokozott figyelembevétele } \\
\text { (kooperáció erósítése) }\end{array}$ & T2: Eszközök múködési ideje (tény) / Eszközök elvárt múködési ideje × 100 \\
\hline Rendszerek magas rendelkezésre állása & T2: Eszközök múködési ideje (tény) / Eszközök elvárt múködési ideje × 100 \\
\hline Üzemelési biztonság elvárt szintjének betartása & S1: Sikertelen hatósági vizsga / hatósági vizsga × 100 \\
\hline Magasan biztosított kockázati szint megtartása & Nincs megfelelő SLA-mutató \\
\hline Környezeti biztonság elvárt szintjének betartása & Nincs megfelelő SLA-mutató \\
\hline Javuló baleseti statisztikák & Nincs megfelelő SLA-mutató \\
\hline Munkatársak képzése, megtartása & Nincs megfelelő SLA-mutató \\
\hline Területi specializáció kialakítása & Nincs megfelelő SLA-mutató \\
\hline Világszínvonalú termelővállalattá válás / s megtartása & S1: Sikertelen hatósági vizsga / hatósági vizsga x 100 \\
\hline Fenntartható vállalatként való múködés & Nincs megfelelő SLA mutató \\
\hline
\end{tabular}

\section{Lábjegyzet}

${ }^{1}$ Csapat, késóbb csoport: a termelő vállalat három munkatársa és a szerzók alkotta munkacsoport.

${ }^{2}$ MSZ EN 15221-1 Létesítménygazdálkodás 1. rész: Szakkifejezések és meghatározásuk.

${ }^{3}$ A teljes lista: MSZ EN 15221-1 Létesítménygazdálkodás 1. rész: Szakkifejezések és meghatározásuk, „A” melléklet, informatív

${ }^{4}$ EN 15341 - Maintenance - Maintenance Key Performance Indicators

\section{Felhasznált irodalom}

Bakacsi Gy. (1996): Szervezeti magatartás, Közgazdasági és Jogi Kiadó, Budapest

Amaratunga, D. - Baldry, D. - Sarshar, M. (2000): Performance Evaluation in Facilities Management: Using the Balanced Scorecard Approach; COBRA Conference

Amaratunga, D. - Baldry, D. (2002): Developing Balanced Scorecards for Facilities Management in Facilities Management Innovation and Performance, Spon Press

Best, R. - Langston, C. - de Valence, R. (2002): Workplace Strategies and Facilities Management., Butterworth Heinemann
Coronel, P. - Evans, A. (1999) : The Balanced Scorecard in Facilities Management, Benchmarking PLUS, Melbourne, August

EN 15341- Maintenance - Maintenance Key Performance Indicators

IFUA Horváth \& Partners (2008): Balanced Scorecard a gyakorlatban, Alinea, Budapest

Kaplan, R.S. - Norton, D.P. (2000): Balanced Scorecard, kiegyensúlyozott stratégiai muta-tószámrendszer: Eszköz, ami mozgásba hozza a stratégiát. KJK-Kerszöv, Budapest

Kaplan, R.S. - Norton, D.P. (1996): Using the balanced scorecard as a strategic management system. Harvard Business Review. Jan.-Feb.

Kaplan, R.S. - Norton, D.P. (2004): Strategy Maps Converting Intangible Assets into Tangible Outcomes, Harvard Business School Press

Keit, A. (ed. 1996): Facilities Management, Theory and Practice, Spon Pres

Cikk beérkezett: 2009. 6. hó

Lektori vélemény alapján véglegesítve: 2009. 8. hó 